\title{
ANAESTHETIC MANAGEMENT OF A PATIENT WITH SINGLE VENTRICLE POSTED FOR LAPAROSCOPIC SURGERY
}

Velagalaburre Yalappa Srinivas ${ }^{1}$, Santhosh Govinda Rao ${ }^{2}$, Mathikere Boregowda Sudarshan ${ }^{3}$

1Professor, Department of Anaesthesiology, MMC\&RI, Mysore, Karnataka, India.

${ }^{2}$ Resident, Department of Anaesthesiology, MMC\&RI, Mysore, Karnataka, India.

${ }_{3}^{3}$ Assistant Professor, Department of Anaesthesiology, MMC\&RI, Mysore, Karnataka, India.

HOW TO CITE THIS ARTICLE: Srinivas VY, Rao SG, Sudarshan MB. Anaesthetic management of a patient with single ventricle posted for laparoscopic surgery. J. Evolution Med. Dent. Sci. 2019;8(04):281-282, DOI: 10.14260/jemds/2019/61

\section{PRESENTATION OF THE CASE}

A twenty-three-year-old lady weighing $46 \mathrm{kgs}$. was admitted for laparoscopic sterilisation. She was a known case of congenital double inlet left ventricle diagnosed in infancy and no intervention had been done. She was asymptomatic and had two uneventful vaginal deliveries and was posted for laparoscopic sterilisation, 2 months after her $2^{\text {nd }}$ delivery.

Her preoperative clinical examination revealed that she had a BMI of 21, Mallamapati class II and clubbing of fingers. Cyanosis was absent and jugular venous pulse was normal. Pulse rate of 90 beats per minute regular rhythm, blood pressure of 110/66 mmHg. On cardiac examination loud S2 and systolic murmur of 5/6 present in pulmonary area.

\section{DIFFERENTIAL DIAGNOSIS}

- $\quad$ Single Ventricle

- Ebstein Anomaly

- $\quad$ Cyanotic Heart Disease

\section{CLINICAL DIAGNOSIS}

P2L2 with Single Ventricle.

\section{PATHOLOGICAL DISCUSSION}

Her ECG showed sinus rhythm and $P$ Pulmonale. Echocardiography showed situs solitus, levocardia, single ventricle physiology, inverted ventricles, hypoplastic right ventricle, pulmonary artery from left ventricle with bulboventricular foramen stenosis, PV gradient of 57/25 $\mathrm{mmHg}$ and normal left ventricular function. Her blood gas analysis showed hypoxia with $\mathrm{PaO} 251 \mathrm{mmHg}$.

Double inlet left ventricle (DILV) is a rare congenital heart disease which comprises $1 \%$ of all congenital heart malformations, ${ }^{1}$ demonstrates single ventricle physiology. In this condition both the atria drain into left ventricle and both aorta and pulmonary artery also will be arising from the same, with a rudimentary right ventricle Great arteries may be normally related, the aorta may be anterior and rightward or leftward or "inverted" in a posterior and leftward orientation. ${ }^{2}$ Both the systemic and pulmonary circulations are in parallel, and thus a delicate balance exists between the two. Any alteration in one circuit leads to opposite change in blood flow in the other circulation. ${ }^{3}$ Anaesthesia for these

'Financial or Other Competing Interest': None.

Submission 23-09-2017, Peer Review 14-01-2019,

Acceptance 22-01-2019, Published 28-01-2019.

Corresponding Author:

Dr. Velagalaburre Yalappa Srinivas,

Professor, Department of Anaesthesiology,

K. R. Hospital, MMC\&RI, Mysore-570001,

Karnataka, India.

E-mail: drsrinivasvy@gmail.com

DOI: $10.14260 /$ jemds $/ 2019 / 61$

\section{(c) $($ () $\odot$}

patients needs a thorough understanding of the physiology in order to maintain stable haemodynamics. We hereby report a case of a patient with Double inlet left ventricle posted for laparoscopic sterilisation.

\section{ANAESTHETIC MANAGEMENT}

A written informed consent was taken from patient after explaining the risks. It was decided to do the procedure under lesser increase in intrabdominal pressure with minimal sedation.

Patient was shifted to operating room with $20 \mathrm{G}$ canula on left upper limb. Patient was premedicated with Inj. Midazolam $1 \mathrm{mg}$, Inj. Fentanyl $40 \mathrm{mcg}$, Inj. Ondansetron $4 \mathrm{mg}$, Inj. Dexamethasone $8 \mathrm{mg}$ given intravenously. Patient was preoxygenated with $100 \%$ oxygen for 3 mins. Patient was induced with intravenous Etomidate $12 \mathrm{mg}$ and maintained on $5 \%$ sevoflurane in $100 \%$ oxygen on spontaneous ventilation with mask, combined with local infiltration of Inj. Lignocaine $2 \% 5 \mathrm{cc}$. Intraoperatively pneumoperitoneum was created with carbon dioxide and patient was positioned in Trendelenburg position with minimal increase in intraabdominal pressure and alteration in haemodynamics. The procedure was uneventful and post operatively patient was conscious and oriented.

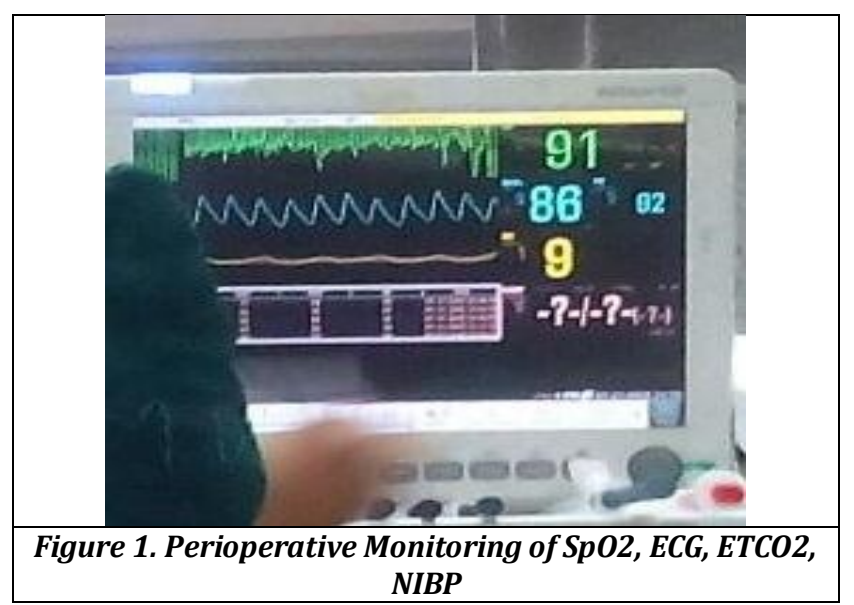

\section{DISCUSSION OF ANAESTHETIC MANAGEMENT}

Congenital heart defects are the most common birth defects. Survival to the adulthood has increased to $70 \%$ with the advancement in surgical and medical management. ${ }^{4}$ The aim of anaesthetic management in such patients is to prevent myocardial depression, to maintain adequate saturation, to prevent the occurrence of air embolism and to prevent other complications such as thrombosis, haemorrhage, infective endocarditis, and paradoxical embolism. ${ }^{5}$ The ventricular interdependence is lost in univentricular hearts, resulting in abnormal systolic and diastolic function of a single ventricle, 
and is more likely to fail under the stress of surgery and anaesthesia,6-8 for which the myocardial depressant drugs should be avoided. ${ }^{9}$ We used etomidate, opioids and sevoflurane, which are safe in these cardiac patients. These patients are at increased risk of desaturation due to associated pulmonary stenosis. Nitrous oxide was avoided to prevent fall in saturation.

\section{FINAL DIAGNOSIS AND CONCLUSION}

DILV is a rare congenital heart disease presenting in adults without any intervention in the childhood which will pose a real challenge to the anaesthesiologist. With detailed preoperative workups and close hemodynamic monitoring during the perioperative period, these patients can experience successful surgical outcomes. This patient with DILV was asymptomatic and well compensated and hence could be managed with minimal anaesthesia.

\section{REFERENCES}

[1] Franklin RC, Spiegelhalter DJ, Anderson RH, et al. Double-inlet ventricle presenting in infancy: I: Survival without definitive repair. J Thorac Cardiovasc Surg 1991;101(5):767-76.

[2] Van Praagh R, Ongley PA, Swan HJ. Anatomic types of single or common ventricle in man: morphologic and geometric aspects of 60 necropsied cases. Am J Cardiol 1964;13(3):367-86.
[3] Zach KJ, Ramakrishna H, Chandrasekaran K, et al. Laparoscopic colectomy in an adult with single ventricle physiology: anesthetic implications and management. Ann Card Anaesth 2015;18(2):252-6.

[4] Feinstein JA, Benson DW, Dubin AM, et al. Hypoplastic left heart syndrome: current considerations and expectations. J Am Coll Cardiol 2012;59(Suppl 1):S142.

[5] Warnes CA, Liberthson R, Danielson GK, et al. Task force 1: The changing profile of congenital heart disease in adult life. J Am Coll Cardiol 2001;37(5):1170-5.

[6] Perloff JK. The univentricular heart. In: The clinical recognition of congenital heart disease. $5^{\text {th }}$ edn. Philadelphia: Saunders 2003: p. 498-516.

[7] Kanter KR. Management of single ventricle and cavo pulmonary connections. In: Sellke FW, Del Nido PJ, Swanson SJ, eds. Sabiston and Spencer - surgery of the chest. Philadelphia: Saunders Elsevier 2010: p. 204155.

[8] Lovell AT. Anaesthetic implications of grown-up congenital heart disease. Br J Anaesth 2004;93(1):12939.

[9] Yuki K, Casta A, Uezono S. Anesthetic management of non-cardiac surgery for patients with single ventricle physiology. J Anesth 2011;25(2):247-56. 